\title{
Genetic Relationships Among Hirado azalea Cultivars and Their Putative Parents Inferred from Flavonoid 3', 5' Hydroxylase Gene Sequences
}

\author{
Sunisa Meanchaipiboon ${ }^{1}$, Nobuo Kobayashi ${ }^{2}$ and Akira Nakatsuka ${ }^{2 *}$ \\ ${ }^{1}$ The United Graduate School of Agricultural Sciences, Tottori University, Tottori 680-8853, Japan \\ ${ }^{2}$ Faculty of Life and Environmental Science, Shimane University, Matsue, Shimane 690-8504, Japan
}

\begin{abstract}
The putative parents of the Hirado azalea (Rhododendron $\times$ pulchrum) are $R$. scabrum, R. ripense, $R . \times$ mucronatum, and other related cultivars. Hirado azalea shows a wide range of flower color variation, but the genetic basis for this color variation is not well understood. In this study, we investigated the anthocyanin pathway gene, flavonoid 3', 5' hydroxylase $\left(F^{\prime}{ }^{\prime} 5^{\prime} H\right)$, by genomic DNA analysis, cDNA sequence analysis, and deduced amino acid sequences to assess the genetic relationships between these taxa, as well as investigating the genetic basis of color variation in this group. In $R$. scabrum and red and pink flowered Hirado azalea cultivars, in which delphinidin (Dp) derivatives are absent, only the exon 2 region was amplified using specific primers in a coding region (CDS) of the $\mathrm{F}^{\prime} \mathbf{5}^{\prime} \mathrm{H}$ gene, except for exon 1, suggesting that the DNA structure of exon 1 is defective in these plants that lack Dp derivatives. On the other hand, $R$. ripense, $R$. macrosepalum, and $R$. yedoense var. poukhanense and $R$. $\times$ mucronatum 'Shiro-ryūkyū', with $D p$ derivatives have normal F3'5'H DNA gene structure. The lengths of the F3'5'H cDNA nucleotide sequences of these wild species were 1533 bp (510 AA), whereas in $R . \times$ mucronatum 'Shiro-ryūkyū', two different sequence lengths were observed-1533 and 1551 bp (510 and 516 AA). R. ripense, $R$. $\times$ mucronatum 'Shiro-ryūkyū', and four purple and white flowered Hirado azalea cultivars were grouped in the same cluster in the F3'5' $H$ gene phylogeny. Among the four Hirado azalea cultivars, the lengths of F3 $^{\prime} 5^{\prime} \mathrm{H}$ in CDS were $1551 \mathrm{bp}$, which included a $5 \mathrm{bp}$ insertion adjacent to the stop codon in 'Ademurasaki' and 'Hakuhō'. However, 'Hirado-no-homare' and 'Shirokujyaku' lacked this insertion and had $1533 \mathrm{bp}$ CDS. When PCR was performed to distinguish the $5 \mathrm{bp}$ insertion, the amplified product was found in some $R$. ripense individuals and $R . \times$ mucronatum 'Shiro-ryūkyū', but not in $R$. scabrum or $R$. macrosepalum. These results suggest that the wide range of flower color in Hirado azalea cultivars is caused by variation in the $F^{\prime}{ }^{\prime} 5^{\prime} H$ genotype derived from hybridization between $R$. scabrum and either $R$. ripense or $R$. × mucronatum 'Shiro-ryūkyū'.
\end{abstract}

Key Words: delphinidin, expressed sequence, flower color, Rhododendron scabrum.

\section{Introduction}

Hirado azalea (Rhododendron $\times$ pulchrum Sweet) comprises a group of evergreen azaleas bred in Nagasaki Prefecture, Japan, especially in the Hirado region (Galle, 1987; Kobayashi, 2016). They are thought to have developed by natural hybridization between garden plants without artificial crossing (Nakao and Tamura, 1970). Hirado azalea is known for their large

Received; June 15, 2020. Accepted; September 18, 2020.

First Published Online in J-STAGE on November 27, 2020.

This research was supported by Grant-in-Aid for Scientific Research (KAKENHI No.18K05617) from the Japan Society for the Promotion of Science (JSPS).

* Corresponding author (E-mail: nakira@life.shimane-u.ac.jp). flowers and various colors including white, pink, red, and purple forms. However, the origin of this color variation is not well understood. The red-flowered R. scabrum G. Don, purple-flowered R. ripense Makino, and white-flowered $R . \times$ mucronatum (Blume) G. Don 'Shiro-ryūkyū' are the putative parents of the Hirado azalea based on their morphologies including flower color, shape, and number of pistils and stamens and almost all cultivars are similar to R. scabrum or $R$. × pulchrum 'Ōmurasaki' (Tamura, 1962, 1963). Moreover, the genetic relationships among evergreen azaleas inferred from DNA markers, including amplified fragment length polymorphism (AFLP), simple sequence repeats (SSR), and expressed sequence tag (EST) markers, indicate that Hirado azalea is most closely related to R. scabrum, and cluster with $R . \times$ mucronatum, 
$R$. ripense, and $R$. macrosepalum Maxim (Scariot et al., 2007a, b). As flavonoid 3', 5' hydroxylase (F3'5'H) plays a key role in flower color diversity in interspecific hybridization between purple flowered R. kiusianum and red flowered R. kaempferi (Mizuta et al., 2014), we investigated its presence and sequence variation to understand the flower color variation and genetic relationships among Hirado azalea and their putative parents.

The major pigments of evergreen azalea petals are anthocyanins and flavonols. Anthocyanins can be classified into two groups: cyanidin $(\mathrm{Cy})$ derivatives and delphinidin (Dp) derivatives. The red-flowers of R. scabrum contain only Cy derivatives and the purpleflowers of $R$. ripense and $R$. macrosepalum contain both $\mathrm{Cy}$ and Dp derivatives as pigments (Mizuta et al., 2009; Meanchaipiboon et al., 2020). Previously, our group has reported correlations of flower color, the pigment composition pattern, and flavonoid biosynthesis-related gene expression among Hirado azalea and their related parents (Meanchaipiboon et al., 2020). The results suggested that the wide range of Hirado azalea flower colors is a result of hybridization, with $R$. scabrum as the base species and $R$.ripense, $R$. macrosepalum or $R . \times$ mucronatum 'Shiro-ryūkyū' as the other species. The latter three wild species and cultivars can produce Dp derivatives through the action of F3'5'H. However, it remains unclear from which of these putative parent taxa the F3'5'H gene in Hirado azalea originates.

In this study, we investigated the genetic relationships among Hirado azalea and their putative parents, $R$. scabrum, R. ripense, and $R . \times$ mucronatum 'Shiroryūkyū', by analyzing the F3' 5 'H gene. Furthermore, we assessed the role of the F3'5'H gene in the origins of purple and white flowers in Hirado azalea.

\section{Materials and Methods}

\section{Plant materials}

Cutting clones of Hirado azalea cultivars were obtained from genuine collections in Hirado city, Nagasaki Prefecture. Evergreen azaleas, including 27 individuals of four wild species, and 19 cultivars from the subgenus Tsutsusi were obtained from the experimental field of Shimane University, Japan (Table 1; Meanchaipiboon et al., 2020). For genomic DNA extraction, $70 \mathrm{mg}$ of young leaves were sampled from each plant. Closed flower buds were collected for RNA extraction and sequence analysis. Each sample was immediately frozen in liquid nitrogen and stored at $-80^{\circ} \mathrm{C}$ until extraction for genomic DNA and total RNA.

\section{DNA extraction and DNA analysis}

DNA amplification was carried out for all samples to

Table 1. The samples used for sequencing and genotyping in this study.

\begin{tabular}{|c|c|c|c|c|}
\hline & & \multicolumn{2}{|c|}{ Anthocyanin composition ${ }^{y}$} & \\
\hline & & Dp derivatives $(-)$ & Dp derivatives $(+)$ & \\
\hline \multirow[t]{3}{*}{ Wild species } & Ser. Scabra & & $R$. ripense 1,2 & \multirow{8}{*}{ PCR amplification and gene cloning } \\
\hline & & & R. macrosepalum 1,2 & \\
\hline & & & R. yedoense var. poukhanese 1 & \\
\hline \multirow[t]{5}{*}{ Cultivars } & Ryūkyū azalea group & & R. × mucronatum 'Shiro-ryūkyū' & \\
\hline & Hirado azalea group & & 'Ademurasaki' & \\
\hline & & & ‘Hirado-no-homare’ & \\
\hline & & & 'Hakuhō' & \\
\hline & & & 'Shiro-kujyaku’ & \\
\hline \multirow[t]{2}{*}{ Wild species ${ }^{\mathrm{z}}$} & Ser. Scabra & R. scabrum $1-8$ & R. ripense $3-13$ & \multirow{14}{*}{ PCR amplification } \\
\hline & & & R. macrosepalum $3,4,5$ & \\
\hline \multirow[t]{12}{*}{ Cultivars } & Hirado azalea group & 'Hinomoto' & 'Taihō' & \\
\hline & & 'Raijin’' & 'Hatsuyuki' & \\
\hline & & 'Heiwa-no-hikari' & & \\
\hline & & 'Hiōgi’ & & \\
\hline & & 'Kumo-no-ue' & & \\
\hline & & 'Shinshō’ & & \\
\hline & & 'Hinode’ & & \\
\hline & & 'Banzairaku' & & \\
\hline & & 'Momoyama' & & \\
\hline & & 'Seibo' & & \\
\hline & & 'Saotome' & & \\
\hline & Ōkirishima group & 'Ōmurasaki' & & \\
\hline
\end{tabular}

\footnotetext{
z These wild species did not have their pigment composition confirmed, except for $R$. scabrum 1, 2.

${ }^{y}$ Hirado azalea and 'Shiro-ryūkyū' have been investigated (Meanchaipiboon et al., 2020).
} 
confirm the presence of the F3'5'H gene among wild species and cultivars. DNA extraction was conducted using the modified CTAB method following Kobayashi et al. (1998). The purified DNA was amplified using F3'5'H primers which include UTR regions in $R . \times$ pulchrum 'Ōmurasaki' F3'5'H (AB289598). The PCR mixture $(10 \mu \mathrm{L})$ contained $1 \times$ Ex-taq buffer, $200 \mu \mathrm{M}$ dNTPs, $0.2 \mu \mathrm{M}$ of each primer (P1: 5'-CACATCTAAG GCAAAACCAC-3' and P2: 5'-AGAGCTGCAAGAGG CACA-3'; FASMAC Co., Ltd., Atsugi, Japan), 0.25 U Ex-taq (TaKaRa Bio Inc., Shiga, Japan), and 5 ng template DNA. Amplification conditions were as follows: preheating at $94^{\circ} \mathrm{C}$ for $2 \mathrm{~min} ; 35$ cycles of denaturation at $94^{\circ} \mathrm{C}$ for $30 \mathrm{~s}$; annealing at $66^{\circ} \mathrm{C}$ for $30 \mathrm{~s}$; extension at $68^{\circ} \mathrm{C}$ for $4 \mathrm{~min}$ : and final extension at $68^{\circ} \mathrm{C}$ for $5 \mathrm{~min}$. The PCR products were run on a $1 \%$ agarose gel. ExcelBand 1KB DNA ladder (DM3100; SMOBIO Technology Inc., Hsinchu, Taiwan) was used as the DNA size marker. When the F3'5'H gene did not amplify with the P1 and P2 primer set, an actin gene $(R . \times$ pulchrum; AB610421) was amplified as a control to check the DNA template. The PCR mixture $(10 \mu \mathrm{L})$ contained $1 \times$ Ex-taq buffer, $200 \mu \mathrm{M}$ dNTPs, $0.2 \mu \mathrm{M}$ of each primer (forward; 5'-AGCAATGTATGTTGCT ATC-3' and reverse 5'-TGATCGAGTTGTAGGTA GT-3'; FASMAC), 0.25 U Ex-taq (TaKaRa Bio), and $5 \mathrm{ng}$ template DNA. Amplification conditions were as follows: preheating at $94^{\circ} \mathrm{C}$ for $2 \mathrm{~min} ; 35$ cycles of denaturation at $94^{\circ} \mathrm{C}$ for $30 \mathrm{~s}$; annealing at $53^{\circ} \mathrm{C}$ for $30 \mathrm{~s}$; extension at $72^{\circ} \mathrm{C}$ for $45 \mathrm{~s}$ : and final extension at $72^{\circ} \mathrm{C}$ for $2 \mathrm{~min}$. The PCR products were run on a $1 \%$ agarose gel. ExcelBand 100 bp DNA ladder (DM2100; SMOBIO Technology) was used as the DNA size marker.

When the 5'-UTR to 3'-UTR region of the F3'5'H gene did not amplify with the $\mathrm{P} 1$ and $\mathrm{P} 2$ primer set, we attempted to amplify exon region 1 with P3 (5'-CTAAA AATGGGCACCCTTGA-3') and P4 (5'-CCAAAAGGA GTGCTTTAATGTT-3') and exon region 2 with P5 (5'-TGAACGGCTACTACATACCCAAGAAC-3') and P6 (5'-AGTTTCAGCCGTTGAGCCTA-3') (Fig. 2A; FASMAC). The PCR mixture $(10 \mu \mathrm{L})$ contained $1 \times$ Extaq buffer, $200 \mu \mathrm{M}$ dNTPs, $0.2 \mu \mathrm{M}$ of each primer, $0.25 \mathrm{U}$ Ex-taq (TaKaRa Bio), and $5 \mathrm{ng}$ cDNA template. Amplification conditions were as follows: preheating at $94^{\circ} \mathrm{C}$ for $2 \mathrm{~min} ; 35$ cycles of denaturation at $94^{\circ} \mathrm{C}$ for $30 \mathrm{~s}$; annealing at $60^{\circ} \mathrm{C}$ for $30 \mathrm{~s}$ (for exon 1 region) or $55^{\circ} \mathrm{C}$ for $30 \mathrm{~s}$ (for exon 2); extension at $72^{\circ} \mathrm{C}$ for $1 \mathrm{~min}$; and final extension at $72^{\circ} \mathrm{C}$ for 1.5 or $1.0 \mathrm{~min} . R$. $\times$ pulchrum 'Ōmurasaki' was used as a positive control. ExcelBand 100 bp DNA ladder (DM2100; SMOBIO Technology) was used as the DNA size marker.

\section{$R N A$ extraction and $c D N A$ synthesis}

RNA extraction and cDNA synthesis were conducted to analyze the length of coding sequences and untranslated regions, and for amino acid sequence analysis.
Total RNA was extracted from the petals using the Hotborate method (Wan and Wilkins, 1994). To avoid DNA contamination, DNA digestion was performed following Mizuta et al. (2010). The total RNA ( $5 \mu \mathrm{g})$ treated with DNase I was reverse-transcribed by oligo (dT) and ReverTra Ace reverse transcriptase (Toyobo Co., Ltd., Osaka, Japan), according to the manufacturer's instructions.

Isolation of the F3'5'H gene and sequence analysis

cDNA sequence analysis was carried out to deduce the amino-acid sequences of F3'5' $\mathrm{H}$ in all sampled individuals for phylogenetic analysis. PCR amplification was performed using flower petal cDNA and a set of F3'5'H primers (P1 and P2; FASMAC). The PCR mixture $(10 \mu \mathrm{L})$ contained $1 \times$ Ex-taq buffer, $200 \mu \mathrm{M}$ dNTPs, $0.2 \mu \mathrm{M}$ of each primer, $0.25 \mathrm{U}$ Ex-taq (TaKaRa Bio), and $5 \mathrm{ng}$ template cDNA. Amplification conditions were as follows: preheating at $94^{\circ} \mathrm{C}$ for $2 \mathrm{~min} ; 35$ cycles of denaturation at $94^{\circ} \mathrm{C}$ for $30 \mathrm{~s}$; annealing at $62^{\circ} \mathrm{C}$ for $30 \mathrm{~s}$; extension at $72^{\circ} \mathrm{C}$ for $2 \mathrm{~min}$; and final extension at $72^{\circ} \mathrm{C}$ for $5 \mathrm{~min}$.

The amplified fragments were cloned into the pGEM-T easy vector (Promega Corporation, Madison, WI, USA) and E. coli HST08 Premium Competent Cells (TaKaRa Bio). They were sequenced using a BigDye Terminator version 3.1 Cycle Sequencing Kit (Applied Biosystems, Foster City, CA, USA) and an ABI PRISM 3100 Genetic analyzer (Applied Biosystems), following plasmid DNA extraction by a FastGene Plasmid Mini kit (Nippon Genetics Co., Ltd., Tokyo, Japan). The nucleotide sequences were analyzed and translated to amino acid sequences using the program GENETYX-win, Version 13.0 (Genetyx Corp., Tokyo, Japan). The nucleotide sequences and protein sequences were aligned, and the phylogenetic tree was constructed using the neighbor-joining (NJ) method and bootstrap analysis (1000 replicates).

\section{Detection of the F3'5'H genotype in wild species and cultivars}

As we found polymorphism in the azalea $F^{\prime} 3^{\prime}{ }^{\prime} H$ gene, we attempted to use PCR to describe the variants of this gene. To confirm the presence of a $5 \mathrm{bp}$ insertion at Exon 2 of the $F 3^{\prime} 5^{\prime} H 2$ gene, samples from $R$. ripense, R. macrosepalum, and Hirado azalea were analyzed by PCR using an F3'5'H2-specific primer set (P7: 5'-CCA AGTGCTTATGCTATGTAGGC-3' and P8: 5'-GAAAC GACGGGAACATTCA-3'; FASMAC). The PCR mixture $(10 \mu \mathrm{L})$ contained $1 \times$ Ex-taq buffer, $200 \mu \mathrm{M}$ dNTPs, $0.2 \mu \mathrm{M}$ of each primer, $0.25 \mathrm{U}$ Ex-taq (TaKaRa Bio), and $5 \mathrm{ng}$ gDNA template. Amplification conditions were as follows: preheating at $94^{\circ} \mathrm{C}$ for $2 \mathrm{~min} ; 35$ cycles of denaturation at $94^{\circ} \mathrm{C}$ for $30 \mathrm{~s}$; annealing at $60^{\circ} \mathrm{C}$ for $30 \mathrm{~s}$; extension at $72^{\circ} \mathrm{C}$ for $15 \mathrm{~s}$; and final extension at $72^{\circ} \mathrm{C}$ for $30 \mathrm{~s}$. The PCR products were run on a $2 \%$ agarose gel. 


\section{Results}

Amplification of the F3'5'H gene in genomic DNA

DNA amplification to confirm the presence of the F3'5'H gene among wild species and cultivars detected the full-length gene (approximately $4 \mathrm{~kb}$ ) in genomic DNA of the taxa with Dp derivatives, i.e. $R$. ripense, $R$. macrosepalum, and $R$. yedoense var. poukhanense (Table 1; Fig. 1B). The band size of the F3'5'H gene was also approximately $4 \mathrm{~kb}$ in Hirado azalea cultivars with Dp derivatives ('Ademurasaki', 'Taihō', 'Hiradono-homare', 'Hakuhō', 'Shiro-kujyaku', and 'Hatsuyuki'), and the white-flowered cultivar $R . \times$ mucronatum 'Shiro-ryūkyū'; 'Hirado-no-homare' also had a band size of approximately $1 \mathrm{~kb}$, suggesting it is heterozygous (Fig. 1B). However, the F3'5'H gene could not be amplified with the P1 and P2 primer set in R. scabrum, which lacks Dp derivatives, as well as five red-flowered ('Hinomoto', 'Raijin', 'Hiōgi', 'Kumono-ue', and 'Heiwa-no-hikari'), and six red-purple flowered Hirado azalea cultivars ('Shinshō', 'Hinode', 'Banzairaku', 'Momoyama', 'Seibo', and 'Saotome') (Fig. 1C). These 19 DNA templates of samples without Dp could normally amplify the actin gene (approximately $550 \mathrm{bp}$ ) as a positive control gene (Fig. 1C). Furthermore, we investigated the CDS using specific primers for each exon in eight $R$. scabrum individuals (Fig. 2A). Exon 2 of the F3'5'H gene was amplified for all these plants, but exon 1 failed to amplify (Fig. 2B, C). Amplification of gDNA from the five red-flowered and six red-purple flowered Hirado azalea cultivars also failed to amplify exon 1 (Fig. 2B), but did amplify exon 2 , for which the band size was approximately $400 \mathrm{bp}$ (Fig. 2C).

\section{F3'5'H cDNA sequence analysis}

Nearly full-length cDNA sequences of $F 3^{\prime} 5^{\prime} H$ were amplified and sequenced from two $R$. ripense plants, two $R$. macrosepalum plants, one $R$. yedoense var. poukhanense plant, one $R . \times$ mucronatum 'Shiroryūkyū' plant, and one plant each of four Hirado azaleas; 'Ademurasaki', 'Hirado-no-homare', 'Hakuhō', and 'Shiro-kujyaku'. A band of approximately $1.5 \mathrm{~kb}$ was detected from 10 Hirado azalea cultivars with purple or white-flowers (data not shown). After cloning the amplified PCR products from wild species, we identified $F 3^{\prime} 5^{\prime} H$ cDNA sequences in both $R$. ripense plants, both $R$. macrosepalum plants, and the $R$. yedoense var. poukhanense plant (DDBJ accession no. LC547905LC547910).

The full-length sequences of the $F 3^{\prime} 5^{\prime} H$ homologue genes contained $27 \mathrm{bp}$ of 5' UTRs, $1533 \mathrm{bp}$ of CDS, and 121 or $135 \mathrm{bp}$ of $3^{\prime}$ UTRs in $R$. ripense and $R$. macrosepalum, respectively (Table 2 ). These genes were named $R r F 3^{\prime} 5^{\prime} H 1$ a from $R$. ripense $1 ; \operatorname{RrF3} 5^{\prime}{ }^{\prime} H 1 b$ from $R$. ripense 2; RmF3'5'H1a from $R$. macrosepalum 1; RmF3'5'H1b1 and RmF3'5'H1b2 from $R$. macrosepalum 2. In $R$. yedoense var. poukhanense, the F3'5'H homologue gene contained 27 bp of 5' UTRs, $1533 \mathrm{bp}$ of CDS, and $135 \mathrm{bp}$ of 3' UTRs. This gene was named $R y F 3^{\prime} 5^{\prime} H 1$ (Table 2). The F3'5'H gene had a length of 510 amino acid residues in the three wild

A)

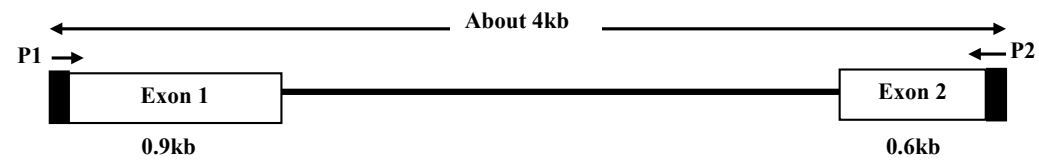

B)
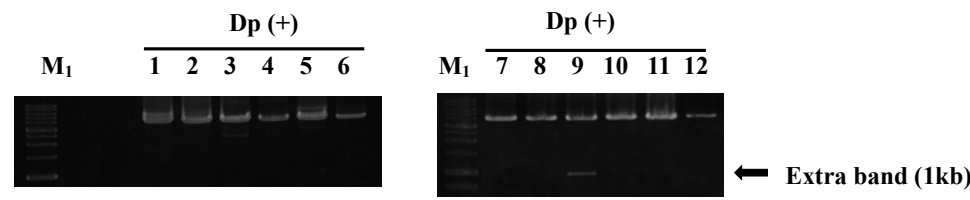

C)
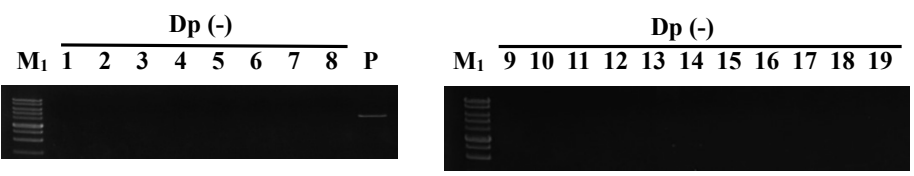

$\begin{array}{llllllllll}M_{2} & 1 & 2 & 3 & 4 & 5 & 6 & 7 & 8 & P\end{array}$

$\begin{array}{llllllllllll}M_{2} & 9 & 10 & 11 & 12 & 13 & 14 & 15 & 16 & 17 & 18 & 19\end{array}$

Actin (550bp)
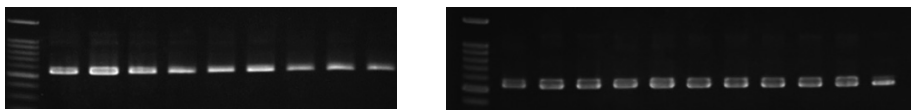

Fig. 1. gDNA analyses of the $\mathrm{F}^{\prime} 5^{\prime} \mathrm{H}$ gene. (A) Diagram of the $\mathrm{F}^{\prime} 5^{\prime} \mathrm{H}$ gene, indicating the primers used for each amplification. (B) and (C) Amplification to assess the presence of the $\mathrm{F}^{\prime}{ }^{\prime}{ }^{\prime} \mathrm{H}$ gene among wild species and cultivars. Dp: Dp derivative production; $\mathrm{M}_{1}: 1 \mathrm{~kb}$ DNA marker (DM3100; SMOBIO Technology) and $\mathrm{M}_{2}: 100$ bp DNA marker (DM2100). (B) Lanes 1-6: R. macrosepalum 1 and 2, R. ripense 1 and 2, R. × mucronatum 'Shiro-ryūkyū' and R. yedoense var. poukhanense 1; lanes 7-12: Hirado azalea cultivars 'Ademurasaki', 'Taihō', 'Hirado-no-homare', 'Hakuhō', 'Hatsuyuki', and 'Shiro-kujyaku. (C) Lanes 1-8: eight individuals of R. scabrum; lanes 9-19: Hirado azalea cultivars 'Hinomoto', 'Raijin', 'Hiōgi', 'Kumo-no-ue', 'Heiwa-no-hikari', 'Shinshō', 'Hinode', 'Banzairaku', 'Momoyama', 'Seibo', and 'Saotome'; P: positive control ('Ōmurasaki’). 
A)

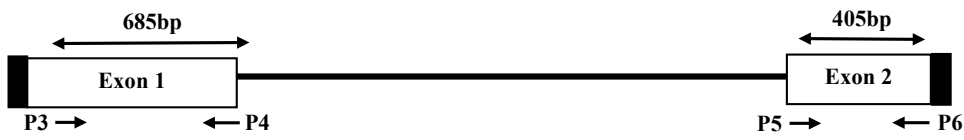

B)

$\begin{array}{llllllllll}M & 1 & 2 & 3 & 4 & 5 & 6 & 7 & 8 & P\end{array}$

$P 3$ and P4

(685bp)
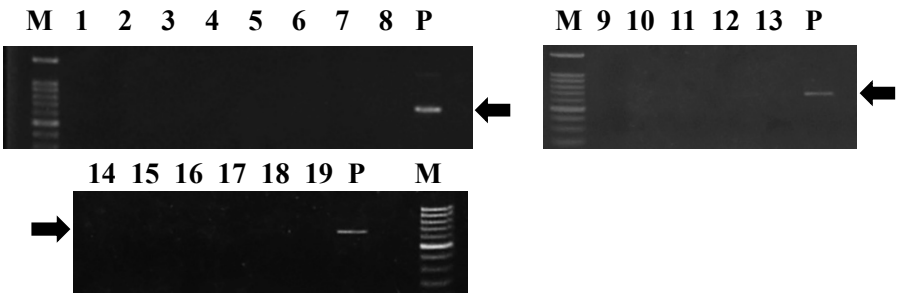

C)

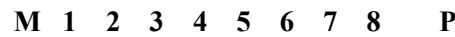

$\mathrm{P5}$ and $\mathrm{P6}$

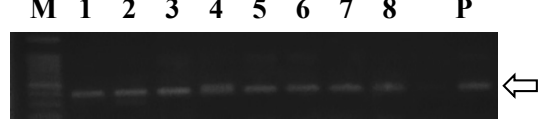

M $9 \begin{array}{lllllll}10 & 11 & 12 & 13 & P\end{array}$

$\begin{array}{llllllll}14 & 15 & 16 & 17 & 18 & 19 & \text { P } & \text { M }\end{array}$
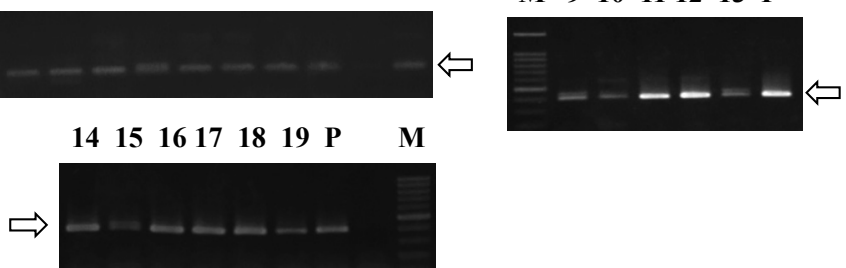

Fig. 2. gDNA analyses of the F3'5'H gene exon 1 and exon 2. (A) Diagram of the $\mathrm{F}^{\prime}{ }^{\prime} 5^{\prime} \mathrm{H}$ gene indicating the primers used for each amplification.

(B) Amplification of F3'5'H exon 1. (C) Amplification of F3'5'H exon 2. For (B) and (C) M: 100 bp DNA marker (DM2100; SMOBIO Technology); lanes 1-8: eight individuals of R. scabrum; lanes 9-19: Hirado azalea cultivars 'Hinomoto', 'Raijin', 'Hioggi', 'Kumo-no-ue', 'Heiwa-no-hikari', 'Shinshō', 'Hinode', 'Banzairaku', 'Momoyama', 'Seibo', and 'Saotome'; P: positive control ('Ōmurasaki'). Black and white arrows indicate $685 \mathrm{bp}$ and $405 \mathrm{bp}$, respectively.

Table 2. The accession numbers and lengths of each region of the F3' $5^{\prime} \mathrm{H}$ gene in wild species and cultivars.

\begin{tabular}{|c|c|c|c|c|c|c|}
\hline & & Gene name & $5^{\prime} \mathrm{UTR}$ & CDS & 3'UTR & Accession no \\
\hline R. ripense 1 & & $\mathrm{RrF}^{\prime} 5^{\prime} \mathrm{H} 1 \mathrm{a}$ & 27 & 1533 & 121 & LC547905 \\
\hline R. ripense 2 & & $\mathrm{RrF}^{\prime} 5^{\prime} \mathrm{H} 1 \mathrm{~b}$ & 27 & 1533 & 135 & LC547906 \\
\hline R. macrospalum 1 & & $\mathrm{RmF}^{\prime} 5^{\prime} \mathrm{H} 1 \mathrm{a}$ & 27 & 1533 & 121 & LC547907 \\
\hline \multirow[t]{2}{*}{ R. macrospalum 2} & & $\mathrm{RmF}^{\prime} 5^{\prime} \mathrm{H} 1 \mathrm{~b} 1$ & 27 & 1533 & 135 & LC547908 \\
\hline & & $\mathrm{RmF}^{\prime} 5^{\prime} \mathrm{H} 1 \mathrm{~b} 2$ & 27 & 1533 & 121 & LC547909 \\
\hline R. yedoense var. poukhanense & & $\mathrm{RyF}^{\prime} 5^{\prime} \mathrm{H} 1$ & 27 & 1533 & 135 & LC547910 \\
\hline \multirow[t]{2}{*}{ R. × mucronatum 'Shiro-ryūkyū' } & & RmSRF3'5'H1 & 27 & 1533 & 135 & LC547911 \\
\hline & & $\mathrm{RmSRF}^{\prime} 5^{\prime} \mathrm{H} 2$ & 27 & 1551 & 122 & LC547912 \\
\hline \multirow[t]{4}{*}{ Hirado azalea group } & 'Hirado-no-homare' & RpHHF3'5'H1 & 27 & 1533 & 135 & LC547913 \\
\hline & ‘Shiro-kujyaku’' & RpSKF3'5'H1 & 27 & 1533 & 135 & LC547914 \\
\hline & ‘Ademurasaki' & $\mathrm{RpF}^{\prime} 5^{\prime} \mathrm{H} 2$ & & & & In this study \\
\hline & ‘Hakuhō’' & $\mathrm{RpF}^{\prime} 5^{\prime} \mathrm{H} 2$ & 27 & 1551 & 108 & In this study \\
\hline Ōkirishima group & 'Ōmurasaki' & $\mathrm{RpF}^{\prime} 5^{\prime} \mathrm{H} 2$ & & & & AB488484 (Mizuta et al., 2010) \\
\hline
\end{tabular}

species.

Interestingly, the $\mathrm{F}^{\prime} 5^{\prime} \mathrm{H}$ gene in $R . \times$ mucronatum 'Shiro-ryūkyū' displayed two different CDS lengths: $1533 \mathrm{bp} \quad\left(R m S R F 3^{\prime} 5^{\prime} \mathrm{H1}\right.$; LC547911) and $1551 \mathrm{bp}$ (RmSRF3'5'H2; LC547912), corresponding to 510 and 516 amino acid residues, respectively (Fig. 4C; Table 2). The F3'5'H gene in Hirado azalea cultivars also had two different CDS lengths: 1533 bp from 'Hirado-nohomare' and 'Shiro-kujyaku' (DDBJ accession no. LC547913-LC547914) as compared to $1551 \mathrm{bp}$ from 'Ademurasaki' and 'Hakuhō', corresponding to 510 and 516 amino acid residues, respectively (Fig. 4C; Table 2). The F3'5'H genes in 'Ademurasaki' and
'Hakuhō' were identical to those of $R . \times$ pulchrum 'Ōmurasaki'. Moreover, Hirado-no-homare' and 'Hakuhō' had different nucleotide sequences that were shorter as a result of deletion (data not shown).

Phylogenetic relationship of the $F 3^{\prime} 5^{\prime} H$ gene among wild species, $R . \times$ mucronatum 'Shiro-ryūkyu', and Hirado azalea

The F3'5'H cDNA of wild species, $R$. $\times$ mucronatum 'Shiro-ryūkyū', and Hirado azalea cultivars was chosen for phylogenetic analysis due to similarities in their F3'5' $\mathrm{H}$ nucleotide sequences. The alignments of nucleotide sequences were compared between the wild 
species, R. $\times$ mucronatum 'Shiro-ryūkyū', and four Hirado azalea cultivars: 'Ademurasaki', 'Hirado-nohomare', 'Hakuhō', and 'Shiro-kujyaku'. Phylogenetic analysis indicated that there are two clusters. $R$. ripense and $R . \times$ mucronatum 'Shiro-ryūkyū' are closely related to Hirado azaleas and were assigned to the same cluster, while R.yedoense var. poukhanense and R. macrosepalum were assigned to another cluster (Fig. 3).

Detection of a 5 bp insertion in the F3'5'H gene of wild species and cultivars

In some Hirado azalea, there was a 5 bp (TTGTA) insertion in the $F 3^{\prime} 5^{\prime} H$ cDNA gene (Fig. 4). PCR investigation with primers specific for this insertion did not amplify the F3'5'H gene in eight $R$. scabrum, eight $R$. ripense and five $R$. macrosepalum individuals or the cultivars 'Taihō', 'Hirado-no-homare', and 'Shirokujyaku', suggesting that these individuals did not have this insertion (Table 3). Amplification of the F3'5'H gene with these primers produced an approximately $300 \mathrm{bp}$ PCR product in five azaleas R. ripense, $R . \times$ mucronatum 'Shiro-ryūkyū', $R . \times$ pulchrum
'Ōmurasaki', and three Hirado azalea cultivars, 'Ademurasaki', 'Hakuhō' and 'Hatsuyuki', suggesting that the $5 \mathrm{bp}$ insertion is present in these cultivars (Table 3).

\section{Discussion}

Although recent genetic studies have found that Hirado azalea is closely related to the red-flowered

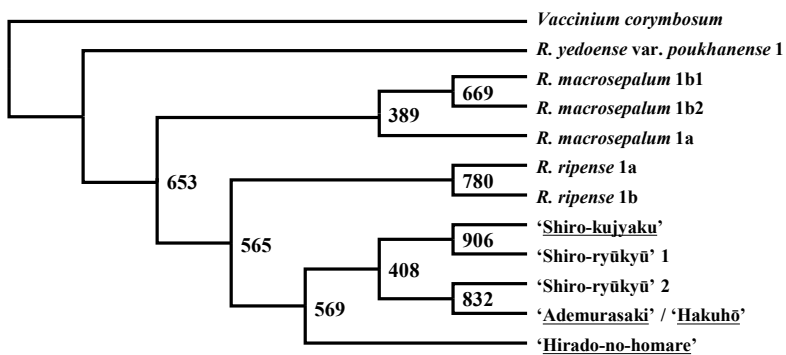

Fig. 3. Neighbor-joining tree of $\mathrm{F}^{\prime} 5^{\prime} \mathrm{H}$ nucleotide sequences among wild species, $R$. × mucronatum 'Shiro-ryūkyū', and four Hirado azalea cultivars (underlined). The numbers at the nodes are bootstrap values. Vaccinium corymbosum was set as an outgroup.

A)

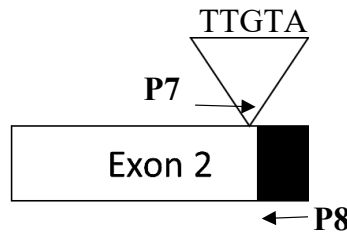

B)

RrF3'5'H1a
RrF3'5'H1b
RmF3'5'H1a
RmF3'5'H1b1
RmF3'5'H1b2
RpHHF3'5'H1
RpSKF3'5'H1
RmSR3'5'H1
RmSR3'5'H2
RpF3'5'H2

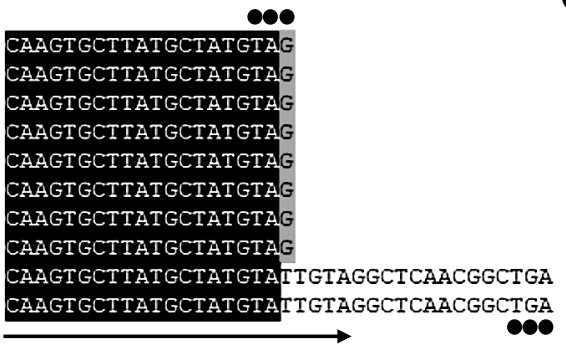

C)

\begin{tabular}{|c|c|}
\hline RrF3'5'H1a & VRLAAI-NT PRLQPSAYAI \\
\hline RrF3'5'H1b & TPLAAYNTPRLQPSAYA \\
\hline RmF3'5'H1a & VPLAARNT PRLQPS \\
\hline RmF3'5'H1b1 & VPLAARVT PRLQP \\
\hline RmF3'5'H1b2 & VPLAAINT PRLQPSAY \\
\hline RpHHF3'5'H1 & VPLAAIVTT PRLQPSAY \\
\hline RpSKF3'5'H1 & VPLAARVT PRLQPSAY \\
\hline RmSR3'5'H1 & VPLAAYVT PRLQPSAYA \\
\hline RmSR3'5'H2 & VPLAAKVIFRLQPSAYA \\
\hline RpF3'5' ${ }^{\prime} 2$ & VPLAALIVI PRLQP SAYA \\
\hline
\end{tabular}

P7

Fig. 4. cDNA sequence analysis. (A) Diagram showing the 5 bp insertion in exon 2 of the F3'5'H gene. Nucleotide sequence (B) and translated amino acid (C) alignments of the exon 2 region of F3'5'H near the insertion. Dots indicate the stop codon (TAG and TGA).

Table 3. PCR analysis of the F $3^{\prime} 5^{\prime} \mathrm{H}$ exon 2 insertion in R. scabrum, R. ripense, R. macrosepalum and Hirado azalea with delphinidin derivatives.

\begin{tabular}{|c|c|c|c|}
\hline & & No insertion & $5 \mathrm{bp}$ insertion \\
\hline \multirow[t]{3}{*}{ Wild species ${ }^{\mathrm{z}}$} & & R. scabrum (8) & \\
\hline & & R. ripense (8) & $R$. ripense (5) \\
\hline & & R. macrosepalum (5) & \\
\hline \multirow[t]{5}{*}{ Cultivars } & Ryūkyū azalea group & & R. × mucronatum 'Shiro-ryūkyū' \\
\hline & Hirado azalea group & 'Hirado-no-homare' & 'Ademurasaki' \\
\hline & & ‘Shiro-kujyaku & 'Hakuhō’' \\
\hline & & ‘Taihō' & 'Hatsuyuki' \\
\hline & Ōkirishima group & & 'Ōmurasaki' \\
\hline
\end{tabular}

\footnotetext{
z The parentheses show individual numbers of wild species.
} 
R. scabrum (Scariot et al., 2007a, b), this does not explain the wide flower color variation in this cultivar group. Our investigation of the $\mathrm{F}^{\prime} 5^{\prime} \mathrm{H}$ gene, which plays a key role in flower color diversity in interspecific hybridization between purple and red azalea flowers (Mizuta et al., 2014; Meanchaipiboon et al., 2020), suggests that flower color variation in Hirado azalea may be due to variations in this gene arising from hybridization of R. scabrum with either $R$. ripense or $R . \times$ mucronatum 'Shiro-ryūkyū'.

PCR analysis of the F3' 5 'H gene from gDNA using $\mathrm{P} 1$ and $\mathrm{P} 2$ primers showed that taxa without Dp derivatives, including certain Hirado azalea, did not have about $4 \mathrm{~kb}$ of a F3'5' $\mathrm{H}$ nucleotide, similar to $R$. ripense or $R . \times$ mucronatum 'Shiro-ryūkyū' (Fig. 1). Eight plants of $R$. scabrum did not have an amplified exon 1 region after PCR using P3 and P4 primers (Fig. 2B). Similarly, exon 1 of red-and red-purple flowered Hirado azalea lacking $\mathrm{Dp}$ derivatives was not amplified but exon 2 was (Fig. 2B, C). We tried to amplify the exon 1 region using another primer set, but PCR products were not detected in almost all tested R. scabrum and Hirado azalea, except for $R$.ripense and $R$. $\times$ pulchrum 'Ōmurasaki' (data not shown). These results suggest that the exon 1 region of the $\mathrm{F}^{\prime} 5^{\prime} \mathrm{H}$ gene is defective in certain Hirado azalea and $R$. scabrum as compared to $R$. ripense or $R$. × pulchrum 'Ōmurasaki'. However, the reason for the defective DNA sequence of the exon 1 region in Dp derivative-lacking cultivars is unclear, so to clarify why F3'5' $\mathrm{H}$ did not function for accumulation of $\mathrm{Dp}$ derivatives, we are going to gather upstream information, including promoter region.

Our results add to the evidence for a loss of F3' 5 'H activity as a source of color variation in plants. In delphinium, genomic PCR analysis indicated that the palepink garden cultivar 'SHP' lacked F3'5'H, suggesting that the F3'5'H gene in 'SHP' may either have a substantial alteration or deletion of the ORF sequence (Miyagawa et al., 2014). In a neutron beam-induced Pisum sativum mutant with pink flowers, it was reported that the deletion of a large part of the ORF region of F3'5'H gene caused the loss of F3'5'H activity (Moreau et al., 2012). Similarly, our results suggest that the redflowered wild species $R$. scabrum may have an alteration or deletion of the F3'5'H ORF sequence.

Phylogenetic analysis of the $\mathrm{F}^{\prime} \mathrm{5}^{\prime} \mathrm{H}$ sequences of Hirado azalea and their putative parents showed that $R$. $\times$ mucronatum 'Shiro-ryūkyū' and $R$. ripense are closely related to Hirado azalea (Fig. 3). In addition, previous SSR marker analyses showed that $R$. ripense and 14 cultivars of $R$. $\times$ mucronatum were clustered with 14 cultivars of $R$. $\times$ pulchrum (Yamamoto et al., 2019). Scariot et al. (2007b) investigated the genetic relationship among evergreen azaleas using AFLP, SSR, and EST markers. The consensus tree for these species and cultivars showed that Hirado azalea such as 'Ademurasaki' and $R . \times$ pulchrum 'Ōmurasaki' are closely related to R. scabrum. Tamura (1962) reported that the flower color of a hybrid between $R$. scabrum and $R$.ripense was similar to $R . \times$ pulchrum 'Ōmurasaki'. Moreover, morphological analysis of $R$. macrosepalum and $R$.yedoense var poukhanense suggested that these wild species were unlikely to be putative parents of Hirado azalea (Tamura, 1962). Our genetic analysis based on the $\mathrm{F}^{\prime} \mathrm{F}^{\prime} \mathrm{H}$ gene sequence support the idea that $R$. macrosepalum and $R$. yedoense var poukhanense are not closely related to Hirado azalea (Fig. 3). In combination, our results and those of previous studies suggest that purple-flowered Hirado azaleas 'Ademurasaki' and $R$. × pulchrum 'Ōmurasaki' developed from hybridization between $R$. scabrum and $R$. ripense or $R$. $\times$ mucronatum.

In lily hybrids, origin lily species were identified using nucleotide sequence alignments of the MYB12 gene that regulates anthocyanin accumulation in tepals. In lilies, Asiatic and Oriental inter-specific hybrid cultivar groups are differentiated with respect to polymorphisms of MYB12 (Yamagishi et al., 2014; Yamagishi and Nakatsuka, 2017). Similarly, we found that nucleotide sequence alignments of the F3'5'H gene of wild species and cultivars are different, resulting in $\mathrm{F}^{\prime} 5^{\prime} \mathrm{H}$ gene polymorphisms. A $5 \mathrm{bp}$ insertion in the $\mathrm{F}^{\prime} 5^{\prime} \mathrm{H}$ gene is found in some cultivars. Therefore, we developed a specific marker to detect polymorphisms in wild species and other cultivars. Investigation of the $5 \mathrm{bp}$ insertion in the $\mathrm{F}^{\prime} 5^{\prime} \mathrm{H}$ gene in the wild species $R$. scabrum, R. ripense and $R$. macrosepalum showed that the insertion was absent from all R. scabrum and $R$. macrosepalum plants, whereas it was present in some $R$. ripense plants and $R . \times$ mucronatum 'Shiro-ryūkyū' (Table 3). This suggests that the wide range of flower color in Hirado azalea may be partially due to the introduction of a $5 \mathrm{bp}$ insertion in the $\mathrm{F}^{\prime} 5^{\prime} \mathrm{H}$ gene from $R$. ripense and $R . \times$ mucronatum 'Shiro-ryūkyū' to R. scabrum.

In this study, we investigated gDNA and cDNA sequences of the $\mathrm{F}^{\prime} \mathrm{S}^{\prime} \mathrm{H}$ gene in wild species and cultivars. The results suggest that Hirado azalea lacking $\mathrm{Dp}$ derivatives has an $\mathrm{F}^{\prime} 5^{\prime} \mathrm{H}$ gene derived from $R$. scabrum, whereas Hirado azalea with Dp derivatives, which shows a wide range of color variation, has $\mathrm{F}^{\prime} 5^{\prime} \mathrm{H}$ genes derived from $R$. ripense or $R$. $\times$ mucronatum 'Shiro-ryūkyū', due to hybridization of these species with R. scabrum. To further clarify the genetic relationships among Hirado azalea and their putative parents-R.scabrum, R. ripense, and $R$. $\times$ mucronatum - we are investigating the $\mathrm{F}^{\prime}{ }^{\prime} 5^{\prime} \mathrm{H}$ gene in additional species and cultivars because the putative parents only make a limited genetic contribution in $R$. scabrum to Hirado azalea with Dp derivatives.

\section{Acknowledgements}

The authors thank the faculty of Life and Environmental Sciences of Shimane University for financial 
support in publishing this report.

\section{Literature Cited}

Galle, F. C. 1987. Azaleas. Revised and enlarged Ed. Timber Press Inc., Portland, Oregon.

Kobayashi, N. 2016. Tsutsuji. p. 151-180. In: M. Shibata (ed.). Hana no hinshu kairyou no nihonshi, Bunkyō, Tokyo (In Japanese).

Kobayashi, N., T. Horikoshi, H. Katsuyama, T. Handa and K. Takayanagi. 1998. A simple and efficient DNA extraction method from the plants, especially from woody plants. Plant Tiss. Cult. Biotech. 4: 76-80.

Meanchaipiboon, S., N. Kobayashi and A. Nakatsuka. 2020. Analyses of pigment compositions and anthocyanin biosynthesis gene expression in Hirado azalea cultivars. Hort. J. 89: 284-291.

Miyagawa, N., Y. Nishizaki, T. Miyahara, M. Okamoto, Y. Hirose, Y. Ozeki and N. Sasaki. 2014. Sequence variations in the flavonoid 3',5'-hydroxylase gene associated with reddish flower phenotypes in three delphinium varieties. Plant Biotech. 31: 83-87.

Mizuta, D., T. Ban, I. Miyajima, A. Nakatsuka and N. Kobayashi. 2009. Comparison of flower color with anthocyanin composition patterns in evergreen azalea. Sci. Hortic. 122: 594 602.

Mizuta, D., A. Nakatsuka, T. Ban, I. Miyajima and N. Kobayashi. 2014. Pigment composition patterns and expression of anthocyanin biosynthesis genes in Rhododendron kiusianum, R. kaempferi, and their natural hybrids on Kirishima mountain mass, Japan. J. Japan. Soc. Hort. Sci. 83: 156-162.

Mizuta, D., A. Nakatsuka, I. Miyajima, T. Ban and N. Kobayashi. 2010. Pigment composition patterns and expression analysis of flavonoid biosynthesis genes in the petals of evergreen azalea 'Oomurasaki' and its red flower sport. Plant Breed. 129: $558-562$.

Moreau, C., M. J. Ambrose, L. Turner, L. Hill, T. H. N. Ellis and J. M. I. Hofer. 2012. The $b$ gene of pea encodes a defective flavonoid 3',5'-hydroxylase, and confers pink flower color. Plant Physiol. 159: 759-768.

Nakao, S. and T. Tamura. 1970. Tutuji-rui. p. 3005-3018. In: R. Ishii and Y. Inoue (eds.). Encyclopedia of horticulture, Vol. 6. Seibundoushinkosha, Tokyo (In Japanese).

Scariot, V., T. Handa and J. De Riek. 2007a. A contribution to the classification of evergreen azalea cultivars located in the Lake Maggiore area (Italy) by means of AFLP markers. Euphytica 158: 47-66.

Scariot, V., E. De Keyser, T. Handa and J. De Riek. 2007b. Comparative study of the discriminating capacity and effectiveness of AFLP, STMS and EST markers in assessing genetic relationships among evergreen azaleas. Plant Breed. 126: 207-212.

Tamura, T. 1962. Kyusyu no tsutsuji. Shinkaki 35: 38-42 (In Japanese).

Tamura, T. 1963. Studies on the Hirado-azaleas, with special reference to their formation. Bulletin of the Horticultural Research Station D: 155-185 (In Japanese with English abstract).

Wan, C. Y. and T. A. Wilkins. 1994. A modified hot borate method significantly enhances the yieldd of high-quality RNA from cotton (Gossypium hirsutum L.). Anal. Biochem. 223: 7-12.

Yamagishi, M. and T. Nakatsuka. 2017. LhMYB12, regulating tepal anthocyanin pigmentation in Asiatic hybrid lilies, is derived from Lilium dauricum and L. bulbiferum. Hort. J. 86: 528-533.

Yamagishi, M., H. Ihara, K. Arakawa, S. Toda and K. Suzuki. 2014. The origin of the LhMYB12 gene, which regulates anthocyanin pigmentation of tepals, in Oriental and Asiatic hybrid lilies (Lilium spp.). Sci. Hortic. 174: 119-125.

Yamamoto, S., T. Nakamura, K. Koiwai, M. Miyano, E. Iizuka, A. Nakayama, Y. Kurashige, N. Kobayashi and T. Handa. 2019. Origin of the Rhododendron kaempferi related species and cultivars estimated by SSR analysis. Acta Hortic. 1263: 295-297. 